\title{
IDENTIFIKASI SIKAP ILMIAH DALAM MELAKUKAN PRAKTIKUM FISIKA PADA PESERTA DIDIK SMAN 12 MAKASSAR
}

\author{
Chaerunnisa Eka Sari* \\ Universitas Negeri Makassar \\ chairunniisa.eka.cc@unm.ac.id \\ Kaharuddin Arafah \\ Universitas Negeri Makassar \\ kaharuddinarafah@unm.ac.id
}

\author{
Ahmad Yani \\ Universitas Negeri Makassar \\ Ahmad.Yani@unm.ac.id \\ *koresponden author
}

\begin{abstract}
Abstrak - Penelitian ini bertujuan untuk mendeskripsikan sikap ilmiah peserta didik dalam praktikum fisika dan untuk mengetahui sikap ilmiah yang dominan muncul pada peserta didik kelas X MIPA 5 SMAN 12 Makassar. Jenis penelitian ini adalah penelitian deskriptif. Subyek penelitian berjumlah 34 orang peserta didik kelas X MIPA. Data hasil penelitian diperoleh dengan menggunakan instrumen lembar observasi sikap ilmiah peserta didik. Hasil penelitian menunjukkan bahwa sikap ilmiah peserta didik kelas X MIPA 5 SMAN 12 Makassar dalam praktikum fisika mengalami peningkatan pada setiap kegiatan praktikum. Sikap ilmiah peserta didik pada praktikum pertama yang termasuk kategori baik adalah sikap rasa ingin tahu $75.49 \%$, bekerja sama $70.59 \%$, bertanggung jawab $79.41 \%$, berpikiran terbuka $67.65 \%$, dan disiplin $66.18 \%$ sedangkan sikap ilmiah peserta didik yang termasuk kategori sangat baik adalah sikap objektif $82.35 \%$. Pada praktikum kedua sikap ilmiah peserta didik yang termasuk dalam kategori baik adalah sikap disiplin $77.94 \%$ sedangkan yang termasuk kategori baik sekali adalah sikap rasa ingin tahu $80.39 \%$, objektif $88.24 \%$, bekerja sama $80.88 \%$, bertanggung jawab $85.29 \%$ dan berpikiran terbuka $83.82 \%$. Pada praktikum ketiga semua indikator sikap ilmiah peserta didik termasuk kedalam kategori baik sekali, sikap rasa ingin tahu $85.29 \%$, objektif $92.65 \%$, bekerja sama $88.24 \%$, bertanggung jawab $91.18 \%$, berpikiran terbuka $92.65 \%$, dan disiplin $82.35 \%$. Pada umumnya, sikap ilmiah peserta didik kelas X MIPA 5 SMAN 12 Makassar yang dominan muncul pada ketiga kegiatan praktikum dengan persentase tertinggi adalah sikap objektif sebesar $87.75 \%$.
\end{abstract}

\section{Kata Kunci : Praktikum Fisika, Sikap Ilmiah, Peserta Didik}

Abstract -.This study aims to describe the scientific attitudes of students in physics practicum and to find out the dominant scientific attitudes appearing in class X MIPA 5 students of SMAN 12 Makassar. This type of research is descriptive research. The research subjects were 34 students of class X MIPA. The data were obtained using the observation sheet instrument of scientific attitudes of students. The results showed that the scientific attitude of students of class X MIPA 5 SMAN 12 Makassar in physics practicum increased in each practicum activity. The scientific attitude of students in the first practicum included in the good category is the attitude of curiosity $75.49 \%$, working together $70.59 \%$, responsible $79.41 \%$, open minded $67.65 \%$, and $66.18 \%$ discipline while the scientific attitude of the students included in the excellent category is the attitude objective is $82.35 \%$. In the second practicum, scientific attitudes of students included in the good category were $77.94 \%$ disciplinary attitudes while those included in the excellent category were curiosity attitudes $80.39 \%$, objective $88.24 \%$, working together $80.88 \%, 85.29 \%$ responsible and $83.82 \%$ open minded. In the third practicum, all indicators of scientific attitudes of students belong to the excellent category, attitudes of curiosity $85.29 \%$, objectives $92.65 \%, 88.24 \%$ cooperation, $91.18 \%$ responsibility, $92.65 \%$ open mindedness, and $82.35 \%$ discipline. In general, the dominant scientific attitudes of students of class X MIPA 5 SMAN 12 Makassar appear in the three practicum activities with the highest percentage being objective attitude is $87.75 \%$.

Keywords : Physics Practicum, Scientific Attitude, Students. 


\section{A. PENDAhULUAN}

Pendidikan merupakan salah satu bentuk upaya peningkatan kualitas sumber daya manusia. Karena pada hakikatnya, fungsi pendidikan adalah untuk mengembangkan kemampuan serta meningkatkan mutu kehidupan dan martabat manusia. pendidikan menjadi sektor penting yang menjadi kebutuhan sekaligus tuntutan yang tidak bisa diabaikan.

Baiknya kualitas pendidikan ditentukan oleh banyak aspek yang saling berkaitan, yakni pendidik atau guru, peserta didik, maupun proses pembelajaran. Dalam pelaksanaan pendidikan, tidak sematamata hanya untuk memperoleh hasil, tetapi proses juga menjadi fokus perhatian. Upaya untuk meningkatkan kualitas pendidikan dapat dilakukan melalui mewujudkan proses pembelajaran yang baik termasuk untuk mata pelajaran Fisika. Dalam pembelajaran fisika harus diperhatikan bagaimana peserta didik mendapatkan pengetahuan, konsep, dan teori melalui pengalaman praktis dengan cara melakukan observasi atau eksperimen secara langsung. Sehingga dalam proses pembelajaran Fisika, siswa dituntut aktif menemukan konsep utama dari materi Fisika baik melalui kegiatan observasi ataupun eksperimen.

Melalui kegiatan praktikum diharapkan peserta didik memiliki kemampuan berfikir dan bertindak berdasarkan pengetahuan sains yang dimilikinya. Pembelajaran fisika memiliki tujuan sebagai pembelajaran yang membekali peserta didik pengetahuan, pemahaman, dan sejumlah kemampuan untuk mengembangkan ilmu pengetahuan dan teknologi. Untuk mencapai tujuan tersebut, maka pembelajaran fisika di sekolah harus menekankan pada pemahaman konsep fisika dengan berlandaskan hakikat IPA yang mencakup produk, proses dan sikap ilmiah. Jika pembelajaran fisika yang dilaksanakan bertujuan agar siswa mampu memahami produk ilmiah (konsep, hukum, azas, teori) berdasarkan proses ilmiah (mengamati, melakukan eksperimen, dll), sehingga menimbulkan sikap ilmiah maka pembelajaran fisika harus melibatkan siswa secara aktif untuk berinteraksi dalam proses pembelajaran. Tujuan pembelajaran yang selama ini dilaksanakan masih berorientasi pada produk atau hasil berupa nilai, sedangkan peran sains untuk membentuk sikap ilmiah masih sering terabaikan.

Penanaman sikap ilmiah akan sangat berpengaruh untuk mencapai hakikat pembelajaran IPA khususnya fisika secara utuh. Sikap ilmiah menjadi indikator yang sangat penting dalam melaksanakan kegiatan ilmiah. Oleh sebab itu, sikap ilmiah dalam melaksanakan kegiatan praktikum menjadi syarat mutlak yang harus diketahui dan dimiliki oleh peserta didik. Praktikum memiliki beberapa tujuan yang sering dikaitkan menurut Hasrudin dan Rezeqi (Atnur, 2015) yaitu: (1) untuk memotivasi siswa sebab kegiatan praktikum pada umumnya menarik bagi siswa sehingga mereka lebih termotivasi untuk belajar sains; (2) untuk mengajarkan keterampilan dasar ilmiah; (3) untuk meningkatkan pemahaman konsep; (4) untuk memahami dan menggunakan metode ilmiah; dan (5) untuk mengembangkan sikap-sikap ilmiah.

Sikap ilmiah merupakan sikap yang harus ada pada diri seorang ilmuwan atau akademisi ketika menghadapi persoalan-persoalan ilmiah. Sikap ilmiah mengandung dua makna yaitu attitude toward science dan attitude of science. Sikap yang pertama mengacu pada sikap terhadap sains sedangkan sikap yang kedua mengacu pada sikap yang melekat setelah mempelajari sains. Jika seseorang memiliki sikap tertentu, orang itu cenderung berperilaku secara konsisten pada setiap keadaan (Ulfa, 2016).

Ada beberapa karakteristik sikap ilmiah yaitu mengembangkan keingintahuan tentang lingkungannya, percaya bahwa setiap akibat ada sebabnya, mempunyai pandangan terbuka, berpikir kritis, bebas dari penyimpangan, menghargai pendapat orang lain mempertahankan kejujuran, kesabaran, ketelitian, kecermatan, dan kedisiplinan (Guswita, 2018:139). 
Sikap ilmiah adalah kecenderungan seseorang untuk berperilaku dan mengambil tindakan berdasarkan ilmu pengetahuan dalam hal ini meliputi indikator rasa ingin tahu, objektif, bekerja sama, tanggung jawab, berpikiran terbuka, dan disiplin.

\section{B. METODE}

Penelitian ini merupakan penelitian deskriptif. Penelitian ini memberikan gambaran mengenai sikap ilmiah dalam melakukan praktikum fisika pada peserta didik. Penelitian ini dilaksanakan pada semester ganjl tahun ajaran 2019/2020 di SMA Negeri 12 Makassar tepatnya pada bulan April Oktober 2019. Adapun subjek dalam penelitian ini adalah peserta didik kelas X MIPA 5 SMA Negeri 12 Makassar sebanyak 34 orang peserta didik.

Indikator sikap ilmiah dalam penelitian ini mencakup sikap rasa ingin tahu, objektif, bekerja sama, tanggung jawab, berpikiran terbuka, dan disiplin. Prosedur pengumpulan data yang dilakukan dalam penelitian ini yaitu melalui lembar observasi sikap ilmiah. dilakukan pada saat praktikum fisika berlangsung yang dilakukan oleh beberapa orang observer sebanyak tiga kali kegiatan praktikum. Lembar observasi digunakan untuk mengetahui kemunculan sikap ilmiah peserta didik pada saat praktikum berlangsung dengan metode check-list. Persentase kemunculan sikap ilmiah yang diperoleh melalui lembar observasi kemudian dikelompokkan berdasarkan indikator dengan kategori sebagai berikut:

\begin{tabular}{cc}
\hline Interval (\%) & Kategori \\
\hline $\mathbf{8 0 - 1 0 0}$ & Baik Sekali \\
$\mathbf{6 6 - 7 9}$ & Baik \\
$\mathbf{5 6 - 6 5}$ & Cukup \\
$\mathbf{4 0 - 5 5}$ & Kurang \\
$<\mathbf{3 9}$ & Kurang Sekali \\
\hline
\end{tabular}

(Arikunto, 2009).

\section{HASIL DAN DISKUSI}

Kemampuan berpikir kritis peserta didik diinterpretasi dengan cara mengaitkan antara indikator kemampuan berpikir kritis dengan jawaban yang diungkapkan saat proses wawancara. Berdasarkan analisis deskriptif data persentase kemunculan sikap ilmiah untuk tiap-tiap indikator sebagai berikut :

Tabel 2. Gambaran sikap ilmiah peserta didik hasil observasi

\begin{tabular}{ccccc}
\hline Indikator Sikap & \multicolumn{4}{c}{ Persentase Kemunculan (\%) } \\
\cline { 2 - 5 } Ilmiah & Praktikum 1 & Praktikum 2 & Praktikum 3 & Rata-rata \\
\hline Rasa ingin tahu & 75.49 & 80.39 & 85.29 & 80.39 \\
Objektif & 82.35 & 88.24 & 92.65 & 87.75 \\
Bekerja sama & 70.59 & 80.88 & 88.24 & 79.90 \\
Tanggung jawab & 79.41 & 85.29 & 91.18 & 85.29 \\
Berpikiran terbuka & 67.65 & 83.82 & 92.65 & 81.37 \\
\hline Disiplin & 66.18 & 77.94 & 82.35 & 75.49 \\
\hline
\end{tabular}

Dari tabel 2 diatas, terlihat bahwa sikap ilmiah peserta didik yang dominan muncul pada ketiga kegiatan praktikum dengan persentase tertinggi adalah sikap objektif sebesar $87.75 \%$.

Sikap rasa ingin tahu merupakan suatu keinginan untuk menyelidiki dan mencari pemahaman fakta atau konsep terhadap sesuatu hal. Butir indikator rasa ingin tahu yang diteliti pada penelitian ini 
meliputi menanyakan setiap langkah kegiatan yang kurang jelas, perhatian pada objek yang diamati, dan antusias pada proses sains. Sebelum melakukan praktikum, peserta didik menanyakan cara penggunaan alat maupun hal-hal yang belum diketahuinya terkait dengan praktikum yang akan mereka lakukan. Saat kegiatan praktikum berlangsung, sebagian besar peserta didik sangat memperhatikan objek yang mereka amati hal tersebut dikarenakan objek atau alat yang digunakan dalam praktikum merupakan hal yang baru dan menarik untuk mereka amati.

Sikap objektif memiliki arti memandang sesuatu sesuai dengan tempat, sifat, dan keadaannya. Butir pernyataan untuk indikator sikap objektif meliputi mempertimbangkan data yang ada sebelum membuat keputusan, dan mengambil keputusan sesuai fakta. Indikator sikap objektif ini merupakan indikator sikap ilmiah yang muncul pada peserta didik dalam kegiatan praktikum dengan persentase tertinggi. Hal tersebut terlihat pada hampir seluruh peserta didik saat mengambil data, mereka terlebih dahulu mencatat data yang telah mereka peroleh pada lembar cakaran, setelah memastikan data tersebut sudah benar barulah mereka menuliskannya pada lembar kerja. Selain itu, peserta didik yang menuliskan hasil praktikum pada lembar kerja sesuai dengan data/fakta yang mereka peroleh.

Sikap bekerja sama memiliki arti sebagai suatu kegiatan yang dilakukan oleh beberapa orang untuk mencapai tujuan bersama. Indikator sikap bekerja sama mengalami peningkatan pada setiap kegiatan praktikum. Peserta didik yang terlihat langsung mengambil bagian tugasnya tanpa membagi tugas dengan teman kelompoknya kemudian ada beberapa orang peserta didik yang tidak turut memberikan kontribusi di dalam kelompoknya. Pada akhir kegiatan praktikum beberapa peserta didik menafsirkan hasil pengamatan tanpa meminta pendapat dari teman kelompoknya.

Sikap bertanggung jawab diartikan sebagai kesadaran diri terhadap sesuatu yang telah atau sedang terjadi. Pada penelitian ini, butir pernyataan untuk indikator sikap bertanggung jawab meliputi menjaga alat dan bahan yang digunakan dalam praktikum dan melaksanakan tugas dan kewajiban yang dibebankan dalam kegiatan praktikum. Indikator sikap bertanggung jawab peserta didik pada setiap kegiatan praktikum mengalami peningkatan. Hal tersebut ditandai dengan peserta didik menjaga dan mengembalikan alat dan bahan yang mereka gunakan dalam kegiatan praktikum dengan baik dan sebagian besar peserta didik telah melaksanakan kewajibannya didalam pelaksanaan praktikum dengan baik.

Sikap berpikiran terbuka dapat dilihat dari kecenderungan menunjukkan kebesaran hati. Butir pernyataan untuk indikator sikap berpikiran terbuka pada penelitian ini meliputi menghargai pendapat/temuan teman dan indikator menerima dan memberikan saran kepada teman.

Sikap disiplin dapat diartikan sebagai kemampuan seseorang untuk dapat mengontrol dirinya menuju tingkah laku yang dapat diterima. Butir pernyataan untuk indikator sikap disiplin yang meliputi memperhatikan dan menaati tata tertib pelaksanaan praktikum dan memanfaatkan waktu dengan efektif dalam pelaksanaan praktikum. Indikator sikap disiplin merupakan indikator sikap ilmiah yang memiliki persentase terendah. Hal tersebut disebabkan karena peserta didik kurang menaati tata tertib di dalam laboratorium ditandai dengan keterlambatan hadir di laboratorium, serta kurangnya pemanfaatan waktu secara efektif pada saat pelaksanaan praktikum karena peserta didik tidak dapat menyelesaikan kegiatan pengambilan datanya sesuai dengan waktu yang telah ditetapkan.

Secara keseluruhan yang diketahui bahwa rata-rata kemunculan sikap ilmiah peserta didik dalam melakukan praktikum fisika mengalami peningkatan pada setiap kegiatan praktikum. Hal tersebut sesuai dengan hasil penelitian yang dilakukan oleh Ulfa (2016) yang menyatakan bahwa pembelajaran 
berbasis praktikum dapat dijadikan salah satu alternatif dalam pembelajaran untuk mengembangkan sikap ilmiah peserta didik.

\section{SIMPULAN}

Berdasarkan hasil dan pembahasan di atas maka dapat disimpulkan bahwa:

1. Sikap ilmiah peserta didik kelas X MIPA 5 SMAN 12 Makassar dalam praktikum fisika mengalami peningkatan pada setiap kegiatan praktikum.

2. Pada umumnya, sikap ilmiah peserta didik kelas X MIPA 5 SMAN 12 Makassar yang dominan muncul pada ketiga kegiatan praktikum dengan persentase tertinggi adalah sikap objektif sebesar $87.75 \%$.

\section{DAFTAR RUJUKAN}

Arikunto, S. (2009). Dasar-Dasar Evaluasi Pendidikan. Jakarta: Bumi Aksara Jensen, E. (2008). Brain Based Learning. Yogyakarta: Pustaka Pelajar.

Guswita, S. (2018). Analisis Keterampilan Proses Sains dan Sikap Ilmiah bagi Siswa Kelas XI pada Mata Pelajaran Biologi di SMA Al-Azhar 3 Bandar Lampung. Bandar Lampung: UIN Raden Intan Lampung.

Ulfa, S. W. (2016). Pembelajaran Berbasis Praktikum: Upaya Mengembangkan Sikap Ilmiah Siswa pada Pembelajaran Biologi. Jurnal Pendidikan Islam dan Teknologi Pendidikan, VI(1), 65-75.

Ulva, V., Ibrohim, \& Sutopo. (2017, Mei 20). Mengembangkan Sikap Ilmiah Siswa SMP Melalui Pembelajaran Inkuiri Terbimbing Pada Materi Ekosistem. Jurnal Pendidikan : Teori, Penelitian, dan Pengembangan, 2(5), 622-626. 